\title{
Penerapan SEM (Sport Education Model) dalam Konteks Kurikulum 2013
}

\author{
Rama Kurniawan ${ }^{2}$ (Kurniawan_8866@yahoo.com) \\ Adang Suherman ${ }^{3}$ (adangsuherman@gmail.com)
}

\begin{abstract}
The aim of this study was to know how the implementation of the curriculum model Sport Education (SE) in the high school based on curriculum 2013.

A total of 34 students (24 girls and 10 boys) in one of the Senior High School in Lamongan were involved in this study. The student groups are given learning scheme by using a curriculum model SE. Data were collected through observation during the learning (14 lessons). Team portfolios analysis were also used to see the extent to which the implementation of the activities of the students in groups.

The research result showed that the activity of the students who refers to characterize the Sport Education program that seasons, team affiliation, formal competition, the culminating event and record keeping) is going well, while activity in the category festivity is enough. Teachers as mediators of learning seen less in encouraging students to conduct festivity, while in other activities, the teacher is able to perform well. For portfolio assessment teams are at level 3. The evidences of the implementation of the Sport Education can be used in the school with curriculum 2013. The existence of a model-based scientific approach such as Sport Education provides an alternative model that can be used in the context of the curriculum 2013 for physical education. Good results from the implementation of the SE which is based on various global studies can be used as a reference as part of efforts to achieve the objectives of physical education in terms of affective, cognitive, and social aspects.
\end{abstract}

Keywords: Curriculum 2013, Physical Education, Sport Education

\begin{abstract}
Abstrak
Tujuan penelitian ini adalah untuk melihat bagaimana penerapan model kurikulum Sport Education di Sekolah Menengah Atas yang didasarkan pada pemberlakuan kurikulum 2013.

Sampel penelitian sebanyak 34 siswa (24 siswa perempuan dan 10 siswa laki-laki) di salah satu Sekolah Menengah Atas Negeri di Lamongan dilibatkan dalam penelitian ini. Kelompok siswa tersebut diberikan skema pembelajaran dengan menggunakan model kurikulum SE. Pengambilan data dilakukan melalui proses pengamatan (observasi) selama skema pembelajaran berlangsung (14 lesson). Analisis dokumen portofolio tim juga digunakan untuk melihat aktivitas siswa dalam kelompok.

Hasil penelitian menggambarkan bahwa aktivitas siswa yang mengacu pada ciri program Sport Education yaitu seasons, team affiliation, formal competition, culminating event dan record keeping) berlangsung dengan baik, sedangkan kegiatan festivity keterlaksanaannya berada pada kategori cukup. Guru sebagai mediator pembelajaran terlihat kurang dalam mendorong siswa untuk melakukan kegiatan festivity. Sedangkan pada kegiatan lain, guru mampu melakukan dengan baik. Untuk penilaian portofolio tim berada pada level 3. Hal ini membuktikan bahwa pelaksanaan Sport Education bisa dilaksanakan pada sekolah yang menerapkan kurikulum 2013. Adanya model pembelajaran yang berbasis scientific approach seperti Sport Education memberikan alternatif model yang bisa digunakan dalam konteks pelaksanaan kurikulum 2013 untuk mata pelajaran pendidikan jasmani, olahraga dan kesehatan. Hasil positif dari penerapan SE yang didasarkan pada berbagai penelitian internasional dapat dijadikan rujukan sebagai salah satu upaya untuk mencapai tujuan pendidikan jasmani baik dari segi afektif, kognitif, gerak maupun hubungan sosial.
\end{abstract}

Kata Kunci: Kurikulum 2013, Pendidikan Jasmani, Sport Education

\footnotetext{
${ }^{2}$ Mahasiswa Magister Program Studi Pendidikan Olahraga, Sekolah Pascasarjana, UPI Bandung

${ }^{3}$ Dosen Program Studi Pendidikan Olahraga, Sekolah Pascasarjana, UPI Bandung
} 


\section{Pendahuluan}

Kurikulum yang berlaku di Indonesia saat ini adalah kurikulum 2006 dan kurikulum 2013. Hal ini sesuai dengan amanat Peraturan Menteri Pendidikan dan Kebudayaan Nomor 160 Tahun 2014 yang menyatakan pemberlakuan kembali kurikulum 2006 bagi sekolah yang baru melaksanakan kurikulum 2013 selama 1 semester dan tetap memberlakukan kurikulum 2013 bagi sekolah yang telah menerapkannya selama 3 semester. Namun setiap sekolah baik di tingkat dasar maupun menengah direncanakan akan serentak menerapkan kurikulum 2013 pada tahun 2019. Keputusan tersebut memberikan kesempatan bagi pemerintah umtuk melakukan evaluasi dan pembenahan demi terciptanya kurikulum yang bisa mewadahi segala potensi dan memberikan arah kemajuan bagi pendidikan di Indonesia. Kata kunci yang sering dikaitkan dengan kurikulum 2013 adalah scientific approach. Sebuah pendekatan yang merangsang siswa untuk terlibat aktif mencari tahu, bereksperimen, mengeksplorasi kemampuan diri dan menggali pengetahuan dari sekelilingnya. Tidak hanya mata pelajaran sains yang dekat dengan materi praktikum dan percobaan, mata pelajaran lain seperti pendidikan jasmani juga dituntut untuk menempatkan siswa sebagai subjek utama dalam proses belajar mengajar di kelas. Adanya penambahan jam pelajaran di sekolah yang saat ini menjadi 3 jam pelajaran memberikan peluang bagi guru pendidikan jasmani (penjas) untuk bekerja keras dalam menyediakan kondisi belajar yang aktif dan menarik bagi siswa.

Tujuan pendidikan jasmani sudah banyak disampaikan oleh para ahli, namun sebagian besar menyatakan bahwa pendidikan jasmani merangsang pertumbuhan dan perkembangan peserta didik (Pangrazi \& Dauer, 1992). Tujuan pendidikan jasmani tentu harus mengarah pada perkembangan pada 5 aspek yaitu fisik, gaya hidup, kognitif afeksi, dan sosial (Bailey, 2006). Selain tujuan-tujuan secara luas, tedapat beberapa tujuan khusus yang dijadikan oleh guru maupun stakeholder sebagai target pendidikan jasmani. Tujuan kebugaran dan kesehatan fisik seringkali menjadi aspek penting dari aktivitas pendidikan jasmani. Seperti yang dilakukan di Amerika Serikat, untuk mencapai kebugaran yang diharapkan pendidikan jasmani dikemas melalui program Health-Related Program (Sallis, dkk., 1997). Sedangkan di Australia, program Sport Education digunakan sebagai media untuk meningkatkan aktivitas fisik dan motivasi siswa (Alexander, dkk., 1996; Perlman, 2011; 2012). Terkait dengan program Sport Education, perkembangannya mulai masif diperkenalkan oleh Siedentop pada tahun 1994 dan terus dikaji melalui penelitian-penelitian di beberapa negara. Namun di Indonesia, kenyataannya sangat jarang guru penjas yang menggunakan program khusus yang tepat untuk mencapai tujuan spesifik siswa berdasarkan kondisi nyata di sekolah mereka. Pelbagai hasil penelitian di luar negeri mengenai dampak positif Sport Education ternyata belum banyak diteliti dan diterapkan di sekolah di Indonesia. Penelitian yang sudah ada masih sebatas dilakukan di tingkat perguruan tinggi (Purwanto, dkk., 2014). Sedangkan artikel lain hanya masih berupa telaah teoritis yang belum disertai fakta empiris di lapangan (Samodra, 2010). Oleh karena itu, peneliti ingin mengetahui bagaimana keterlaksanaan model kurikulum Sport Education dalam konteks kurikulum 2013. Lebih rinci pertanyaan penelitian yang disusun dalam penelitian ini adalah:

a. Bagaimana keterlaksanaan aktivitas guru dan siswa dalam penerapan model kurikulum Sport Education di sekolah menengah atas?

b. Bagaimana keterlaksanaan aktivitas siswa dalam kelompok terkait dengan penerapan model kurikulum Sport Education di sekolah menengah atas?

c. Bagaimana gambaran ketersediaan portofolio tim terkait dengan penerapan model kurikulum Sport Education di sekolah menengah atas? 


\section{Landasan Teori}

\section{Sport Education}

Sport Education (SE) merupakan sebuah model kurikulum yang dikembangkan oleh Siedentop pada tahun1994. Model ini diperkenalkan pertama kali pada Commonwealth Games Conference di Brisbane Australia (Siedentop, 2002). Siedentop (1998) mengatakan bahwa " $S E$ is a curiculum and instruction model designed to provide authentic, educationally rich sport experiences for girls and boys in the context of school physical education". Dengan kata lain bahwa model kurikulum ini didesain dalam rangka memberikan pengalaman nyata kepada siswa mengenai keterlibatan dalam aktivitas olahraga yang disesuaikan dengan konteks pendidikan jasmani di sekolah. Selain di Australia (Alexander, dkk. 1998), model ini sudah banyak dikaji dan digunakan sebagai kurikulum pendidikan jasmani di Selandia Baru (Grant, 1992), Inggris (Wallhead \& Ntoumanis, 2004), dan juga Korea (Kim, dkk., 2006).

Siendetop dalam Metzler (2000) menyebutkan tiga tujuan utama SE yaitu untuk membangun olahragawan (siswa) yang kompeten (competent), mengerti (literate), dan antusias (enthusiastic). Siswa yang competent dimaksudkan pada kemampuan yang cukup untuk berpartisipasi dalam permainan yang baik, mengerti dan dapat melaksanakan strategi yang tepat di dalam permainan yang rumit. Sedangkan siswa yang literate dimaknai sebagai kemampuan memahami peraturan, ritual, dan tradisi olahraga serta dapat membedakan antara latihan olahraga yang buruk dan yang baik, apakah olahraga anak-anak atau olahraga profesional. Tujuan enthusiastic dijadikan target agar siswa dapat berpartisipasi, memelihara, serta menjaga nilai-nilai olahraga, baik perannya sebagai anggota kelompok olahraga, maupun partisipan yang antusias dalam pengembangan olahraga lokal, nasional, maupun level internasional.

Aktivitas model kurikulum Sport Education memiliki enam ciri utama yang dapat memberi identitas unik (Siedentop, Hastie, dan Van der Mars, 2011). Masing-masing gambaran merupakan adaptasi dari karaktersistik manajemen olahraga yang nyata. Keenam ciri utama tersebut antara lain:

\section{Musim (Seasons)}

SE menggunakan musim yang berarti periode yang lebih lama termasuk periode latihan, sebelum pertandingan, pada saat pertandingan, dan setelah pertandingan dengan pertandingan grand final.

2. Keanggotaan (Team Affiliation)

Siswa menjadi anggota tetap dalam suatu tim yang sama untuk seluruh musim. Hal ini memberi memberikan kesempatan kepada mereka tentang afektif, dan bekerjasama meraih tujuan, membuat keputusan kelompok, pengalaman berhasil dan gagal sebagai satu tim. Adanya kelompok juga memberikan kontribusi perasaan yang kuat terhadap diri sendiri serta keterlibatannya sebagai anggota kelompok.

3. Kompetisi resmi (Formal Competition)

Siswa membuat banyak keputusan tentang susunan dan pelaksanaan di suatu musim. Mereka dapat memodifikasi peraturan pertandingan. Jadwal kompetisi resmi memberikan kesempatan bagi setiap tim dan pemainnya untuk dapat membuat keputusan jangka pendek dan jangka panjang pada musim tersebut. Jadwal kompetisi akan membuat setiap tim dan para pemain fokus dalam latihan dan persiapan.

4. Pertandingan puncak (Culminating Event)). 
Musim yang berakhir dengan pertandingan puncak biasanya dimainkan dengan beberapa pilihan sistem pertandingan: turnamen round-robin, kompetisi tim, atau kompetisi individual, baik satu pertemuan maupun sistem home away.

5. Pencatatan (Record Keeping)

Pertandingan yang berlangsung memberikan peluang untuk membuat catatan penampilan yang bisa digunakan sebagai strategi berlatih, motivasi di dalam dan diantara tim. Catatan dapat menjadi mudah atau sulit, tergantung bakat siswa. Dengan membuat catatan umum, mereka membantu menyediakan latar belakang untuk jadwal kompetisi, seperti pada saat tim dengan sistem pertahanan terbaik akan bersiap melawan tim dengan sistem penyerangan terbaik. Statistik permainan dapat digunakan oleh pelatih dan pemain untuk menganalisis kekuatan tim mereka sendiri dan juga lawan.

6. Pesta (Festivity).

Event olahraga dikenal karena kemeriahannya, karena itu podium juara bisa didesain dan diwarnai dengan corak yang menarik. Pada skala yang kecil, tanpa mengurangi event itu sendiri, siswa dapat melakukan selebrasi kemenangan bagi tim juara.

\section{Pelaksanaan SE}

Fitur-fitur pembelajaran yang terjadi dalam skema SE seperti yang dikutip dari buku Instructional Models for Physical Education (Metzler, 2000) antara lain fitur pemilihan isi (content selection) dimana terdapat pilihan-pilihan untuk memilih jenis olahraga yang dipertandingkan dan skema kompetisi yang tepat untuk digunakan. Fitur managerial control berlangsung untuk mengatur pada pemilihan tugas dan peran pada saat kompetisi (pelatih, manager pertandingan, wasit, dll). Fitur task presentation memuat tampilan tugas dalam rangka pengembangan keterampilan dan strategi tim baik sebelum maupun pada saat pertandingan berlangsung. Dalam model kurikulum, ada dua peran yang dilakukan oleh siswa yaitu sebagai pemain dan peran sebagai petugas pertandingan seperti hakim garis, statistician. Peran tersebut diatur dalam fitur engagement pattern. Dalam hal ini, siswa dibebani oleh tugas dan tanggungjawab mereka masing-masing sesuai dengan peran yang mereka peroleh. Fitur instructional interaction akan tampak pada interaksi siswa terkait kerjasama kelompok dalam satu tim maupun dalam tim perangkat pertandingan. Meski guru menjadi sumber utama pembelajaran, namun pembelajaran tetap dominan pada interaksi siswa satu dengan siswa lainnya. Fitur pacing terlihat ketika siswa mempersiapkan kompetisi, menentukan adanya kompetisi pre-season dan persiapan pertandingan resmi hingga grand final berlangsung. Fitur terakhir yaitu fitur task progression yang mengharuskan siswa membuat bentuk-bentuk latihan yang didasarkan pada evaluasi kemampuan anggota timnya dan statistik pemain pada saat bertanding.

Hal yang menjadi sisi penguat adanya peluang model kurikulum SE untuk memenuhi identitas scientific approach yang diterapkan oleh kurikulum 2013 adalah dominansi aktivitas yang berpusat pada siswa. Siswa juga memiliki peluang besar dalam mendesain pembelajaran mereka. Desain pembelajaran SE seperti yang terlihat pada gambar di bawah ini: 


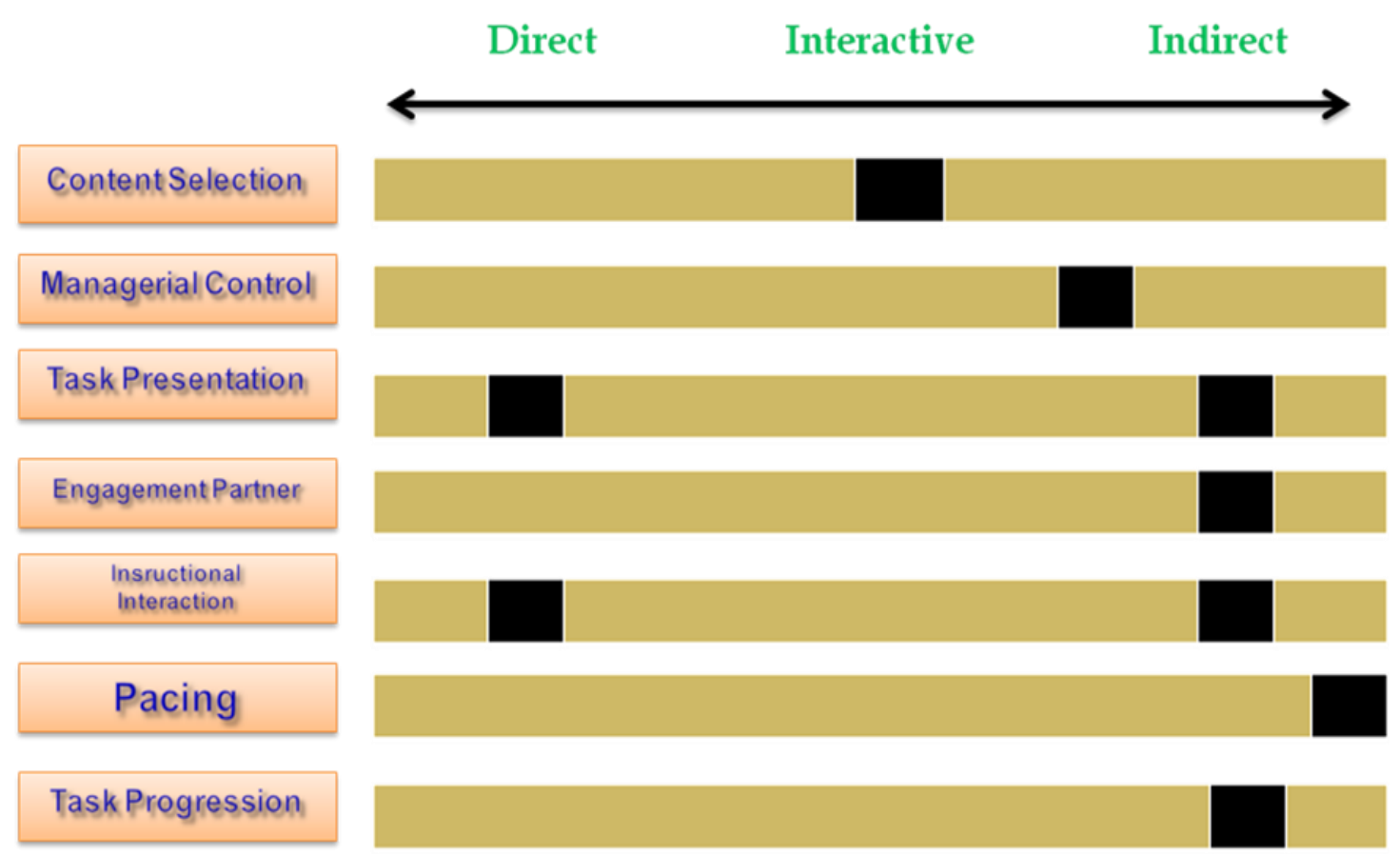

Gambar. Teaching and Learning Features for Sport Education (Metzler, 2000)

Pola aktivitas dominan yang terdapat dalam fitur-fitur model kurikulum SE adalah indirect Instruction yaitu pengajaran yang tidak banyak dikendalikan oleh guru dan menyediakan kesempatan seluas-luasnya kepada siswa untuk berkreasi sesuai dengan tuntutan belajar yang telah ditetapkan.

Penilaian dalam SE

Dalam pembelajaran berbasis SE, siswa akan memiliki peran ganda. Peran pertama yaitu menjadi kesatuan tim bermain yang terdiri dari pemain, pelatih, maupun kapten. Peran yang lainnya akan dilakukan ketika kelompok lain terlibat dalam pertandingan atau sering disebut nonplaying role. Nonplaying role terdiri dari kesatuan tugas manager pertandingan, wasit, pencatat statistik, linesman, retriever dan lain-lain. Kedua peran inilah yang menjadi landasan penilain terhadap keberhasilan belajar siswa.

Proses penilaian siswa dalam model kurikulum bisa dilakukan dengan beberapa cara diantaranya penilaian otentik dan penilaian berbasis portofolio.

- Penilaian otentik

Menurut Mintah (2003) penilaian otentik dalam pendidikan jasmani merupakan penilaian yang berfokus pada produk/hasil dan kualitas penampilan. Dalam prosesnya, siswa sangat aktif terlibat di dalamnya. Contoh dari penilaian otentik ini meliputi penilaian terhadap tingkat aktivitas fisik siswa, motivasi, self-efficacy, pengembangan diri, dan lain-lain. Dalam penilaian-penilaian tersebut siswa mengetahui cara mereka mengevaluasi kemampuan yang mereka miliki pada saat pembelajaran.

- Penilaian portofolio

Pendapat Kirk yang dikutip oleh Kinchin (2001) menjelaskan bahwa penilaian portofolio sangat efektif digunakan karena melibatkan pembelajaran individu dengan dokumen hasil belajar siswa. Penilaian portofolio juga mendorong siswa untuk bertanggungjawab dan belajar secara aktif serta menyediakan dokumentasi perkembangan hasil belajar siswa. Dokumentasi 
tersebut kemudian selanjutnya dijadikan evaluasi untuk menyusun program penjas yang dibutuhkan oleh masing-masing siswa. Dalam SE terdapat beberapa penilaian portofolio yang dilakukan melalui aktivitas berkelompok dan individu. Penilaian portofolio tersebut diantaranya adalah:

\section{Tabel. Penilaian Berdasarkan Tujuan Sport Education}

\begin{tabular}{l|c|c|c}
\hline \multicolumn{1}{c}{ Artifact } & Competence & Literacy & Enthusiasm \\
\hline $\begin{array}{l}\text { Self-Assessment of } \\
\text { Performance }\end{array}$ & $\sqrt{ }$ & \\
\hline Rules Test & & $\sqrt{ }$ & \\
\hline Fair-Play Awards & & & $\sqrt{ }$ \\
\hline Peer Skills Test & $\sqrt{ }$ & & \\
\hline Role Evaluation & & $\sqrt{ }$ & \\
\hline Activity Log/Diary & & & $\sqrt{ }$ \\
\hline
\end{tabular}

(Kinchin, 2001)

Validasi melalui Studi Ilmiah

Sebagai salah satu model pembelajaran yang berpeluang besar menumbuhkan rasa kepemimpinan, tanggungjawab, dan kerjasama sebagai dampak adanya perilaku olahraga (Dyson., dkk. 2004), SE juga memiliki banyak dampak positif lainnya. Hal tersebut diperoleh melalui kajian yang komprehensif dan meluas yang dilakukan oleh pakar di bidang penjas. Dari Aspek keterampilan motorik, SE terbukti dapat meningkatkan keterampilan siswa (Hastie, dkk., 2013). Dengan menggunakan olahraga atletik sebagai fokus permainan juga diperoleh adanya peningkatan pemahaman terhadap aturan pertandingan. Kajian ilmiah yang dilakukan oleh Carlson dan Hastie (1997) menghasilkan temuan bahwa program SE memberikan peningkatan interaksi antara siswa. Interaksi tersebut yang kemudian mendorong adanya peningkatan sikap personal maupun sosial seperti kerjasama dan kepemimpinan. Sedangkan pada kajian lain diperoleh penegasan bahwa SEM mampu meningkatkan partisipasi keterlibatan siswa dalam aktivitas fisik menjadi meningkat dibanding dengan model konvensional yang sering digunakan di sekolah (Hastie \& Trost, 2002). Penelitian tersebut berupaya menggunakan model konvensional sebagai kelompok pembanding. Untuk meraih dan meningkatkan motivasi siswa dalam pendidkan jasmani, SE berhasil menjadi alternatif utama yang bisa dilakukan oleh guru penjas saat ini. Hal ini terbukti dengan hasil penelitian yang dilakukan oleh Wallhead dan Ntoumanis (2004) yang menghasilkan kesimpulan bahwa penerapan SE meningkatkan motivasi siswa sekolah menengah terhadap mata pelajaran penjas di sekolah. Fitur-fitur yang terdapat dalam SEM terbukti mampu memberikan dampak positif bagi siswa seperti situasi yang dibuat menjadi kompetisi resmi memberikan budaya fairplay yang mengarah pada peningkatan social skill siswa (Vidoni \& Ward, 2009) dan keterlibatan secara aktif terhadap belajar secara kelompok yang didorong oleh fitur team affiliation (Mc Phail, dkk., 2004).

\section{Metode Penelitian}

Subyek Penelitian

Siswa sebanyak 34 dilibatkan dalam penelitian ini. Seluruh siswa berasal dari kelas XI di salah satu SMA Negeri di kota Lamongan yang sudah menerapkan kurikulum 2013. 


\section{Prosedur Penentuan Sampel}

Teknik pengambilan sampel yang digunakan dalam penelitian ini adalah teknik cluster random sampling yaitu teknik yang dilakukan dengan cara memilih tingkatan kelas kemudian mencari kelompok (kelas) yang akan menjadi subjek penelitian dari populasi yang ada.

Instrumen

Instrumen yang digunakan dalam penelitian ini terdiri dari:

1. Lembar observasi.

Lembar observasi dibuat berdasarkan konsep ciri dari model kurikulum Sport Education. Ciri tersebut yaitu aktivitas seasons, team affiliation, formal competition, culminating event, record keeping dan festivity. Lembar observasi yang telah dibuat selanjutnya dilakukan expert judgement oleh pakar.

Pengamatan observasi dilakukan oleh 2 guru penjas di tingkat sekolah menengah dan 1 guru penjas di tingkat sekolah dasar. Untuk pengamatan aktivitas season berlangsung di lesson ke 2 hingga 15. Aktivitas affiliation berlangsung pada lesson 2 hingga 14, sedangkan pengamatan aktivitas formal competition dan record keeping berlangsung pada lesson ke 10 hingga 14. Untuk aktivitas culminating event dilakukan pengamatan pada lesson ke 14 sedangkan aktivitas festivity dilakukan pada lesson ke 15.

2. Analisis Dokumen

Dalam pelaksaan pembelajaran, siswa diminta mengisi dokumen-dokumen penilaian individu dan kelompok. Dokumen tersebut terdiri dari self-assessment of performance, rules test, fair-play awards, peer skills test, role evaluation, dan activity log/diary. Hanya dokumen role evaluation yang diisi oleh guru. Dokumen tersebut digunakan sebagai penilaian otentik yang kemudian di dokumentasikan bersama dengan profil msing-masing tim.

\section{Prosedur Penelitian}

Kedua kelompok (kelas) menerima pembelajaran penjas satu kali seminggu. Penelitian ini berlangsung selama 5 minggu dengan setiap pertemuan dilakukan selama 3 x 45 menit. Pembelajaran dilakukan dengan mengikuti tahapan skenario berikut:

Tabel. Skenario Pembelajaran

\begin{tabular}{|c|c|c|}
\hline Skema & Program Sport Education & $\begin{array}{c}\text { Model } \\
\text { Pembelajaran }\end{array}$ \\
\hline Durasi & 5 minggu & - \\
\hline Lama tiap lesson & 45 menit & \\
\hline \multirow[t]{2}{*}{ Materi } & Net games (bolavoli) & \\
\hline & $\begin{array}{c}\text { Fokus Aktivitas } \\
\end{array}$ & \\
\hline Lesson 1 & $\begin{array}{l}\text { - Pengenalan Program SE } \\
\text { - Pengenalan Kejuaraan }\end{array}$ & Direct \\
\hline $2-3$ & - Keterampilan passing dan service & Kooperatif \\
\hline $4-5$ & - Keterampilan Smashing dan Bloking & \\
\hline $6-7$ & - Taktik dan Strategi bermain & \\
\hline $8-9$ & $\begin{array}{ll}\text { - Persiapan } & \text { organisasi/menejemen } \\
\text { pertandingan } & \end{array}$ & \\
\hline $10-11$ & Pertandingan Pre-season & \\
\hline
\end{tabular}




\begin{tabular}{ccc}
\hline 12-14 & Pertandingan kompetisi sistem gugur & \\
& Final & \\
Lesson 15 & Festivity (Perayaan) & Inkuiri \\
\hline
\end{tabular}

Pelaksanan observasi dilakukan pada lesson 2 hingga lesson 15. Lesson pertama tidak dilakukan pengamatan karena hanya memuat penjelasan program kepada siswa dan diskusi terkait kompetisi, pembentukan tim dan deskripsi tugas dari masing-maisng peran yang dilakukan oleh siswa diluar tuntutan sebagai pemain (performer).

Desain Penelitian

Jenis penelitian yang digunakan adalah penelitian kualitatif dengan pendekatan studi kasus. Menurut Creswell (2013), studi kasus merupakan penelitian di mana di dalamnya peneliti menyelidiki secara cermat suatu program, peristiwa, aktivitas, proses, atau sekelompok individu. Pada penelitian ini difokuskan pada pengamatan terhadap keteerlaksanaan suatu program yaitu program SE.

Analisis Data

Analisis Observasi

Analisis yang digunakan terhadap lembar observasi aktivitas guru dan siswa adalah analisis deskriptif kualitatif yaitu dengan cara mencari jumlah keseluruhan dari setiap item observasi kemudian selanjutnya dirata-ratakan berdasarkan jumlah observer. Tahapan berikutnya dicari nilai persentase dengan cara membagi nilai yang diperoleh dengan nilai maksimal. Nilai persentase kemudian dikategorikan berdasarkan norma yang telah dibuat. Kategori terdiri dari kategori "Kurang", "Cukup", "Baik", dan "Sangat Baik".

Analisis Dokumen Portofolio

Creswell (2013) menyatakan bahwa selama proses penelitian kualitatif, peneliti dapat mengumpulkan dokumen-dokumen publik maupun pribadi. Analisis dokumen dilakukan dengan cara melihat ketersediaan dokumen, penggunaannya serta kelengkapan profil masingmasing tim. Kategori analisis dikoding berdasarkan ketersediaan dokumen rubrik portofolio yang diadopsi dari penelitian Kinchin (2001). Kategori terdiri dari level 1 hingga level 4.

\section{Hasil Penelitian}

\section{Analisis Deskriptif}

Analisis deskriptif digunakan untuk mengetahui sebaran data dari kedua instrumen yang digunakan.

Data observasi aktivitas Siswa dan Guru

Data ini diperoleh dari hasil pengamatan aktivitas siswa selama pembelajaran berlangsung. Berdasarkan analisis yang dilakukan didapatkan nilai rata-rata aktivitas siswa dari berbagai komponen aktivitas yaitu season sebesar (63.67), affiliation (164), formal competition (33.33) culminating event (3), record keeping (33.67) dan festivity (4).

Tabel. Deskripsi Hasil Observasi Aktivitas Siswa

\begin{tabular}{lccccc}
\hline \multicolumn{1}{c}{ Komponen } & \multicolumn{3}{c}{ Observer } & \multirow{2}{*}{ Total } & \multirow{2}{*}{ Mean } \\
\cline { 2 - 4 } \multicolumn{1}{c}{ Aktivitas Siswa } & $\mathbf{1}$ & $\mathbf{2}$ & $\mathbf{3}$ & & \\
\hline Season & 64 & 65 & 62 & 191 & 63.67 \\
Affiliation & 166 & 164 & 162 & 492 & 164.00
\end{tabular}




\begin{tabular}{lccccc} 
Formal Competition & 32 & 36 & 32 & 100 & 33.33 \\
Record Keeping & 31 & 37 & 33 & 101 & 33.67 \\
Culminating event & 3 & 3 & 3 & 9 & 3 \\
Festivity & 4 & 5 & 4 & 13 & 4 \\
\hline
\end{tabular}

Sedangkan hasil pengamatan terhadap aktivitas guru dalam mengontrol pelaksanaan model kurikulum Sport Education memiliki sebaran rata-rata yaitu season sebesar (63.67), affiliation (153.33) formal competition (31.67) culminating event (3), record keeping (30.33) dan festivity (5).

Tabel. Deskripsi Hasil Observasi Aktivitas Guru

\begin{tabular}{lccccc}
\hline \multicolumn{1}{c}{$\begin{array}{c}\text { Komponen } \\
\text { Aktivitas Guru }\end{array}$} & $\mathbf{1}$ & $\mathbf{2}$ & $\mathbf{3}$ & \multirow{2}{*}{ Total } & \multirow{2}{*}{ Mean } \\
\cline { 2 - 4 } & 65 & 61 & 65 & 191 & 63.67 \\
Season & 163 & 147 & 150 & 460 & 153.33 \\
Affiliation & 34 & 32 & 29 & 95 & 31.67 \\
Formal Competition & 35 & 29 & 27 & 91 & 30.33 \\
Record Keeping & 4 & 2 & 3 & 9 & 3 \\
Culminating event & 4 & 7 & 3 & 14 & 5 \\
Festivity & & & & & \\
\hline
\end{tabular}

Persentase keterlaksanaan dari masing-masing aktivitas yaitu pada aktivitas siswa menunjukkan kategori "baik" pada aktivitas seasons, team affiliation, formal competition, dan record keeping. Sedangkan untuk aktivitas culminating event dan festivity siswa hanya berlangsung "cukup". Interpretasi tersebut didapat dari hasil prosentase aktivitas siswa yang menunjukkan nilai seasons sebesar 84, affiliation (87), formal competition (83), record keeping (84). Nilai prosentase culminating event sebesar 75 dan festivity 54.

Hasil persentase aktivitas guru tidak jauh berbeda dengan hasil persentase siswa. Guru hanya berada pada kondisi "cukup" dalam melaksanakan ciri model kurikulum SE pada culminating event dan festivity. Sebaliknya pada aktivitas seasons, team affiliation, formal competition, dan record keeping guru mampu melaksanakan dengan baik. Ini didasarkan pada interpretasi data yang menunjukkan prosentase sebesar 84 untuk seasons, 82 untuk affiliation, 79 untuk formal competition dan 76 untuk record keeping. Sedangkan kategori cukup pada aktivitas guru dalam culminating event dan festivity diperoleh dari nilai prosentase 58. Berikut ini merupakan gambaran prosentase dari kedua hasil observasi:

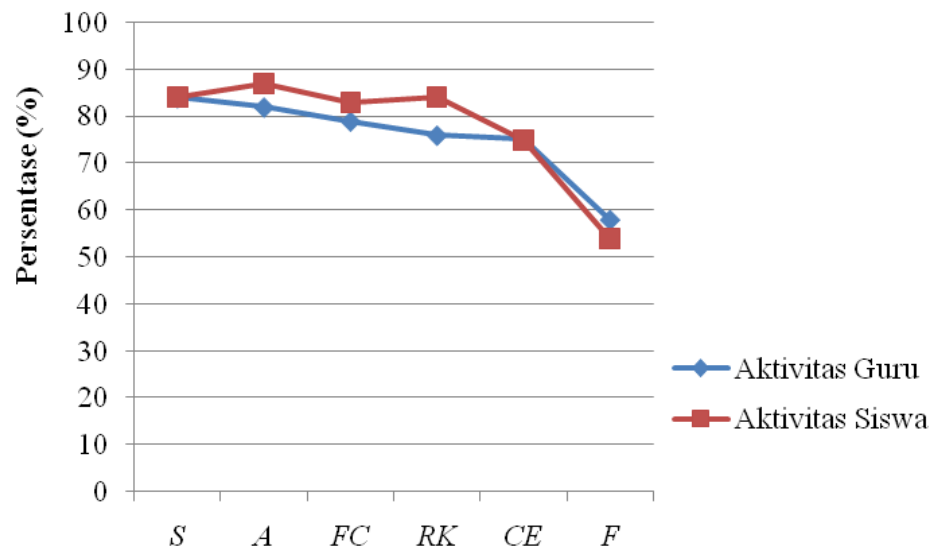

Grafik. Persentase Aktivitas Siswa Dan Guru 


\section{Portofolio Tim}

Berdasarkan gambaran ketersediaan dokumen yang ada, didapatkan hasil sebagai berikut:

Tabel. Dokumen Portofolio Tim

\begin{tabular}{l|l|r}
\hline \multicolumn{2}{c}{ Ketersediaan dalam Dokumen Kelompok } & \multicolumn{2}{c}{ Kategori } \\
\hline Judul & $\sqrt{ }$ & \\
Daftar Isi & $\sqrt{ }$ & \\
Filosofi Tim & $\sqrt{ }$ & Level 3 \\
Profil Pemain & $\sqrt{ }$ & \\
Penilaian Tim & $\sqrt{ }$ & \\
Entri Jurnal/Log & $\sqrt{ }$ & \\
\hline
\end{tabular}

Dalam pelaksanaan pembelajaran penjas dengan model kurikulum SE, siswa melakukan penilaian individu maupun kelompok yang kemudian dikumpulkan menjadi kesatuan dokumen tim yang berisi judul dokumen, daftar isi dari dokumen tersebut, filosofi penamaan tim dan semangat bekelompok. Dalam dokumen tersebut juga terdapat profil anggota tim yang berisi kelebihan dan kekurangannya serta terhadap dokumen penilaian seperti self-assessment of performance, rules test, fair-play awards, peer skills test, role evaluation, dan entri jurnal kegiatan tim.

\section{Simpulan}

Tujuan dari penelitian ini adalah melihat bagaimana penerapan model kurikulum Sport Education ( $S E$ ) di Sekolah Menengah Atas yang didasarkan pada pemberlakuan kurikulum 2013. Hasil dari penelitian ini mengindikasikan bahwa pelaksaanan model kurikulum Sport Education terbukti mampu diterapkan dalam Sekolah Menengah Atas. Berdasarkan aktivitas guru dan siswa semua ciri model kurikulum berlangsung baik kecuali culminating event dan festivity yang cenderung kurang berhasil dilakukan. Padahal menurut Kinchin, dkk. (2009) mayoritas siswa sangat senang dan antusias terhadap final (culminating event) dan festivity (perayaan ) juara dari kompetisi. Berdasarkan hasil penelitian diketahui bahwa aktivitas siswa yang kurang terlaksana dengan baik pada festivity juga diikuti oleh persentase aktivitas guru yang kurang. Hal ini memberikan kesimpulan sementara bahwa guru kurang mendorong adanya pelakanaan festifity dengan baik dalam pelaksanaan SE di akhir kejuaraan/kompetisi.

Dengan adanya penelitian ini, diharapkan guru berani menerapkan SE di Sekolah Menengah Atas (SMA) yang telah menggunakan kurikulum 2013. Beberapa penjelasan terkait pelaksanan SE di SMA diantaranya adalah adanya konsep bahwa olahraga dan permainan merupakan salah satu aspek yang diajarkan secara universal di semua tingkatan sekolah (Tannehil, 1998). Selain itu, waktu belajar penjas yang disediakan oleh kurikulum 2013 sebanyak 3 jam pelajaran setiap minggu memberikan peluang bagi guru untuk menerapkan SE yang pada dasarnya membutuhkan durasi lesson yang cukup panjang. Materi yang digunakan tidak banyak mengubah rancangan materi yang ada dalam kurikulum, karena untuk tingkat SMA, pelaksanaan SE tidak diperlukan modifikasi permainan/olahraga.

Jika guru dan siswa berhasil menciptakan suasana pembelajaran berbasis model kurikulum SE, maka ada beberapa manfaat yang bisa didapatkan oleh keduanya (Hastie, 1998). Manfaat yang diperoleh siswa meliputi potensi perkembangan baik keterampilan psikomotor, kognitif dan sosial yang merata baik bagi siswa yang memiliki keterampilan tinggi maupun keterampilan rendah. Sedangkan manfaat yang bisa diperoleh oleh guru antara lain membebaskan diri mereka dari dominasi direct teaching. Dengan demikian guru bisa 
memfokuskan diri pada kebutuhan spesifik dari tiap individu siswa, penilaian kepada siswa serta tujuan penjas yang lain yang dibutuhkan oleh siswa. Peran guru tersebut sesuai dengan karekteristik utama dari kurikulum 2013 yang menekankan pada peran siswa yang dominan (student centered).

Dari segi acuan proses penilaian, kurikulum 2013 yang saat ini sedang disempurnakan oleh pemerintah tidak jauh berbeda dengan pelaksanaan penilaian pada SE. Berdasarkan Permendikbud No. 66 Tahun 2013 tentang Standar Penilaian Pendidikan, terdapat dua penilaian yang bisa dilakukan oleh guru dan siswa yaitu penilaian otentik dan portofolio. Begitupun juga dengan pelaksanan SE, dua penilaian tersebut dapat menunjang adanya perbaikan dari sisi evaluasi yang mengarah pada kualitas penjas yang lebih baik. Perbaikan yang berfungsi untuk memaksimalkan transfer of learning pengalaman gerak kepada siswa sangat diperlukan guna memberikan bekal bagi mereka untuk kehidupan di masa mendatang (Kirk, 2004).

Namun demikian, penelitian ini memiliki banyak keterbatasan, antara lain penggunaan sampel penelitian. Di masa mendatang diharapkan ada penelitian yang lebih luas dan komprehensif dengan menggunakan sampel yang lebih besar dan jangkauan sekolah yang lebih luas. Penelitian selanjutnya diharapkan mampu mencari penyebab konsep festivity yang masih sulit dikembangkan dalam sekolah yang menggunakan model kurikulum 2013. Penelitian dengan menggunakan permainan dan cabang olahraga yang lain juga sangat diperlukan guna mengkonfirmasi hasil penelitian ini.

\section{Daftar Pustaka}

Alexander, K., dkk. (1996). A spring in their steps? Ossibilities for professional renewal through sport education in Australian schools. Sport, Education and Society, 1, hlm. 23-46. Abstrak.

Alexander, K., dkk. (1998). The sport education crusade down under. Journal of Physical Education, Recreation and Dance, 69 (4), hlm. 21-22.

Bailey, R. (2006). Physical education and sport in schools: A Review of benefits and outcomes. Journal of School Health, 76 (8), hlm. 397-401.

Creswell, J. W. (2013). Research design : Pendekatan kualitatif, kuantitatif, dan mixed. Diterjemahkan oleh Achmad Fawaid. Yogyakarta: Pustaka Pelajar

Dyson, B., dkk. (2004). Sport education, tactical games and cooperative learning: Theoritical and pedagogical considerations. Quest, 56, hlm. 226-240.

Grant, B.C. (1992). Integrating sport into the physical education curriculum in New Zealand secondary schools. Quest, 44, hlm. 304-316.

Hastie, P. A. (1998). Applied benefits of the sport education models. Journal of Physical Education, Recreation and Dance, 69 (4), hlm. 24-26.

Hastie, P. A., \& Trost, S. G. (2002). Student physical avtivity levels during a season of sport education. Pedatric Exercise Science, 14, hlm. 64-74.

Hastie, P. A., dkk. (2013). The development of skill and knowledge during a sport education session of track and field athletics. Research Quarterly for Exercise and Sport, 84, hlm. 336-344.

Kim, J. dkk., (2006). 'Not business as usual': Sport Education pedagogy in practice. European Physical Education Review, 12, hlm. 361-379.

Kinchin, G. D. (2001). Using team portfolios in a sport education seasons. Journal of Physical Education, Recreation and Dance, 72 (2), hlm. 41-44.

Kinchin, G. D., dkk. (2009). Pupils' and teachers' perceptions of a culminating festival within a sport education season in Irish primary schools. Physical Education and Sport Pedagogy. 14 (4), hlm. 391-406. 
Kirk, D. (2004). Framing quality physical education: the elite sport model or Sport Education?. Physical Education and Sport Pedagogy, 9 (2), hlm. 185-195.

MacPhail, A., dkk. (2004). Sport education: promoting team affiliation through physical education. Journal of Teaching in Physical Education, 23, hlm. 106-122.

Metzler, M. W. (2000). Instructional models for physical education. Boston: Allyn and Bacon.

Mintah, J. K. (2003). Authentic assessment in physical education: prevalence of use and perceived impact on students' self-concept, motivation, and skill achievement. Measurement in Physical Education and Exercise Science, 7 (3), hlm. 161-174.

Pangrazi, R.P. dan Dauer, V.P. (1992). Dynamic physical education for elementary school children. 10th Ed. New York: Macmillan Publishing Company.

Peraturan Menteri Pendidikan dan Kebudayaan Nomor 160 Tahun 2014 tentang Pemberlakuan Kurikulum Tahun 2006 dan Kurikulum Tahun 2013.

Peraturan Menteri Pendidikan dan Kebudayaan Nomor 66 Tahun 2013 tentang Standar Penilaian Pendidikan.

Perlman, D. (2011). Examination of self-determination within the sport education model. AsiaPacific Journal of Health, Sport and Physical Education, 2, hlm. 79-92.

Perlman, D. (2012). The influence of the Sport Education Model on amotivated students' inclass Physical activity. Europan Physical Education Review, 18, hlm. 335-345.

Purwanto, S., Susanto, E., Pahalawidi, C. (2014). Pendidikan karakter dengan pendekatan sport education dalam perkuliahan di jurusan pendidikan olahraga UNY. Jurnal Pendidikan Karakter, IV (1), hlm. 48-60.

Sallis, J., dkk. (1997). The effect of a 2-year physical pducation program (SPARK) on physical activity and fitness in elementary school student. American Journal of Public Health, 87 (8), hlm. 1328-1334.

Samodra, Y. (2010). Model pembelajaran direct teaching dan sport education model. Jurnal ILARA, I (2), hlm. 41-47.

Siedentop, D. (2002). Sport education: A retrospective. Journal of Teaching in Physical Education. 21, hlm. 409-418.

Siedentop, D., Hastie, P., dan Van der Mars, H. (2011). Complete guide to sport education. 2th Edition. Champaign : Human Kinetics.

Siedentop. D. (1998). What is sport education and how does it work?. Journal of Physical Education, Recreation and Dance, 69 (4), hlm. 18-20.

Tannehil, D. (1998). Introduction. Journal of Physical Education, Recreation and Dance, 69 (4), hlm. 16-17.

Vidoni, C. \& Ward, P. (2009). Effects of fair play instruction on student social skills during a middle school sport education unit. Physical Education and Sport Pedagogy, 14 (3), hlm. 285-310.

Wallhead, T. \& Ntoumanis. (2004). Effects of a Sport Education Intervention on Students' Motivational Responses in Physical Education. Journal of Teaching in Physical Education, 23, hlm. 4-18.

Sudjana, Nana. 2010. Dasar-Dasar Proses Belajar Mengajar. Bandung: Remaja Rosdakarya.

Yunus, M. 1992. Olahraga Pilihan Bolavoli. Jakarta: Departemen Pendidikan dan Kebudayaan.

Tim penyusun.2009. Buku Pedoman Usulan Penelitian Dan Penulisan Skripsi, Jombang: STKIP PGRI JOMBANG 